MaPan : Jurnal Matematika dan Pembelajaran

p-ISSN: 2354-6883 ; e-ISSN: 2581-172X

Volume 5, No 2, December 2017 (236-250)

DOI: https://doi.org/10.24252/mapan.v5n2a6

\title{
PENGEMBANGAN BAHAN AJAR MATEMATIKA BERBASIS MASALAH UNTUK MEMFASILITASI PENCAPAIAN KEMAMPUAN PENALARAN PADA POKOK BAHASAN PERBANDINGAN KELAS VII MTSN MODEL MAKASSAR
}

\author{
Siti Nurhidayati1), Thamrin Tayeb2), Baharuddin'3) \\ 1,2,3Jurusan Pend. Matematika Fakultas Tarbiyah dan Keguruan UIN Alauddin Makassar \\ 1,2,3Kampus II: Jalan HM. Yasin Limpo Nomor 36 Samata-Gowa \\ E-mail: snurhidayati97@gmail.com¹), thamrin.tayeb@uin-alauddin.ac.id²), \\ bohe.nuny@gmail.com ${ }^{3)}$
}

Submitted: 17-10-2017, Revised: 14-11-2017, Accepted: 24-11-2017

\begin{abstract}
Abstrak:
Penelitian ini merupakan penelitian pengembangan yang bertujuan mengembangkan dan menilai kualitas bahan ajar matematika berbasis masalah untuk memfasilitasi pencapaian penalaran siswa pada pokok bahasan perbandingan yang valid, praktis dan efektif. Jenis penelitian yang digunakan adalah penelitian Research $\mathcal{E}$ Development $(R \mathcal{E} D)$ dengan mengacu pada model 4-D (Four D Models) yaitu Define, Design, Develop and Disseminate. Subjek coba dalam penelitian ini adalah siswa kelas $\mathrm{VII}_{6}$ MTsN Model Makassar dengan jumlah 40 siswa. Berdasarkan hasil uji coba terbatas yang dilakukan, diperoleh bahwa (a) hasil validasi bahan ajar adalah 4,71 pada kategori sangat valid karena setiap aspek untuk setiap jenis perangkat berada pada interval $4 \leq M \leq 5$, (b) praktis karena berdasarkan hasil pengamatan keterlaksanaan bahan ajar yang dikembangkan menunjukkan bahwa rata-rata semua komponen pengamatan keterlaksanaan adalah 1,97 dan berada pada kategori terlaksana seluruhnya (praktis) atau berada pada interval 1,5 $\leq \bar{X} \leq 2$, dan (c) efektif karena telah memenuhi empat kriteria yang menjadi acuan yaitu hasil belajar siswa tercapai karena $85 \%$ siswa mencapai skor 75 , aktivitas siswa dikatakan ideal, karena telah memenuhi kriteria batas toleransi pencapaian waktu ideal yang digunakan, hasil rata-rata kemampuan guru mengelola pembelajaran yang diperoleh yaitu 3,83 dan berada pada kriteria tinggi dalam interval 3,5 $\leq K G<$ 4,5 , dan hasil respon siswa adalah $89,25 \%$ pada kategori positif karena lebih dari $50 \%$ siswa yang memberikan respon positif. Sehingga dapat disimpulkan bahwa pada tahap uji coba terbatas dilaksanakan, bahan ajar matematika berbasis masalah telah memenuhi kriteria kevalidan, kepraktisan, dan keefektifan.
\end{abstract}

Kata Kunci: Bahan Ajar, Berbasis Masalah, Kemampuan Penalaran 


\title{
DEVELOPING PROBLEM-BASED MATHEMATICS TEACHING MATERIALS TO FACILITATE THE ACHIEVEMENT OF REASONING ABILITY ON COMPARISON AT THE CLASS VII OF ISLAMIC JUNIOR HIGH SCHOOL MODEL MAKASSAR
}

\begin{abstract}
:
The aim is of this study developing and assessing the quality of problem-based mathematics teaching materials to facilitate the achievement of students reasoning on comparison subject, basedon validity, practical, and effective comparison. The type of this research is Research $\mathcal{E}$ Development $(R \mathcal{E} D)$ study with reference to 4-D model suggested by Thiagarajan (1974) which includes defining, designing, defeloping and disseminating. The subjects of this research were the students at class VII6 of Islamic Junior High School Model Makassar with a total of 40 students. Based on the results of a limited trial conducted, it was found that (a) the result of the teaching materials validation is 4.71 which is in the category is very valid because every aspect for each type of device is at the intervals of $4 \leq M \leq 5$, (b) It is practical because the observation result of the implementation of the developed learning material shows that the average of all observational components of the implementation is 1.97 which is in category of fully executed (practical) or at the intervals of $1.5 \leq \bar{X} \leq 2$, and (c) it is effective because it has met the four referencedcriteria; that is the result of student' learning is achieved, because $85 \%$ of students achieve the score of 75 ; it can be said, students'activities is ideal, because it has fulfilled the criteria of tolerance limit of the ideal achievement used; the result of the average teacher ability to manage learning is 3.8; and it is in high criterion in the intervals of $3.5 \leq K G<4.5$; and the studens' response outcames are $89.25 \%$ which is in the positive category, because more than $50 \%$ of students have positive responses. Therefor, it can be concluded that when the limited trial stage was implemented, the problem-based mathematics material had met the validity, practicality, and effectiveness criteria.
\end{abstract}

Keywords: Teaching Materials, Problem-Based, Reasoning Ability

How to Cite: Nurhidayati, S., Tayeb, T., \& Baharuddin. (2017). Pengembangan Bahan Ajar Matematika Berbasis Masalah Untuk Memfasilitasi Pencapaian Kemampuan Penalaran Pada Pokok Bahasan Perbandingan Kelas VII MTsN Model Makassar. MaPan : Jurnal Matematika dan Pembelajaran, 5(2), 236-250.

$\mathrm{P}$ enalaran menurut Turmudi (2008) merupakan proses berpikir untuk menarik kesimpulan atau membuat pernyataan baru yang didasarkan pada pernyataan sebelumnya dan kebenarannya telah dibuktikan. Kemampuan penalaran matematis merupakan suatu kemampuan yang harus dikembangkan secara konsisten dengan menggunakan berbagai macam aspek dasar penalaran (Susiana, 2013). Melalui penalaran matematis, siswa diharapkan dapat mengajukan dugaan kemudian menyusun bukti dan melakukan manipulasi terhadap 
permasalahan matematika serta menarik kesimpulan dengan benar dan tepat.

Menurut Depdiknas (2008) kemampuan bernalar menjadi salah satu tujuan dilaksanakan pembelajaran matematika di sekolah yaitu melatih cara berpikir dan bernalar dalam menarik kesimpulan, mengembangkan kemampuan memecahkan masalah, serta mengembangkan kemampuan menyampaikan informasi atau ide-ide melalui lisan, tulisan, gambar, grafik, peta, diagram, dan sebagainya.

Menurut Buhaerah (2011), berdasarkan hasil survey IMSTEP-JICA salah satu penyebab rendahnya kualitas pemahaman siswa dalam matematika adalah bahwa dalam pembelajaran matematika guru terlalu berkonsenrasi pada hal-hal yang prosedural dan mekanistik, pembelajaran berpusat pada guru, siswa hanya dilatih menyelesaikan banyak soal tanpa pemahaman yang mendalam. Akibatnya, kemampuan penalaran dan kompetensi strategis siswa tidak berkembang sebagaimana mestinya.

Salah satu kecenderungan yang menyebabkan siswa gagal menguasai dengan baik pokok-pokok bahasan dalam matematika yaitu siswa kurang memahami dan menggunakan nalar yang baik dalam menyelesaikan soal yang diberikan. Berdasarkan hasil penelitian yang dilakukan oleh Rosnawati (2013), rata-rata persentase yang paling rendah yang dicapai oleh peserta didik Indonesia adalah dalam domain kognitif pada level penalaran yaitu $17 \%$. Hal ini menunjukkan perlunya peningkatan kemampuan penalaran siswa di sekolah dasar dan menengah.

Menurut National Council of Teacher Mathematics (NCTM) dalam pelaksanaan pembelajaran matematika, guru harus memperhatikan lima kemampuan matematis yaitu: koneksi (connections), penalaran (reasoning), komunikasi (communication), pemecahan masalah (problem solving), dan representasi (representation). Oleh karena itu, guru memiliki peranan dalam menumbuhkan kemampuan penalaran matematis dalam diri siswa baik dalam bentuk metode pembelajaran yang dipakai, maupun dalam evaluasi berupa pembuatan soal yang mendukung.

Untuk memfasilitasi kemampuan penalaran matematis siswa perlu didukung oleh pendekatan pembelajaran yang tepat sehingga tujuan pembelajaran dapat tercapai. Menurut Sumartini (2015), salah satu model pembelajaran yang dianggap dapat memfasilitasi kemampuan penalaran siswa adalah pembelajaran berbasis masalah. Pembelajaran berbasis masalah (problembased learning) adalah suatu pembelajaran yang 
menggunakan masalah dunia nyata sebagai suatu konteks bagi peserta didik untuk belajar tentang cara berpikir kritis dan keterampilan pemecahan masalah serta untuk memperoleh pengetahuan dan konsep yang esensial dari materi pembelajaran. Pembelajaran berbasis masalah (problem based learning) dirancang terutama untuk membantu siswa mengembangkan keterampilan berpikir, keterampilan menyelesaikan masalah, dan keterampilan intelektualnya. Selain itu, dalam memfasilitasi kualitas penalaran siswa, diperlukan sebuah alat untuk menfasilitasinya. Salah satunya adalah bahan ajar yang didesain khusus untuk memudahkan para pengajar mendidik siswanya dalam memfasilitasi kemampuan penalarannya.

Oleh karena itu, diperlukan upaya nyata yang tepat, direncanakan dengan matang, dan dikaji dengan seksama agar kemampuan siswa dalam penalaran matematika dapat tumbuh dan berkembang sesuai dengan potensi siswa masing-masmg. Salah satu upaya yang akan dilakukan adalah mengembangkan sebuah bahan ajar yang difokuskan untuk memfasilitasi kemampuan pealaran siswa terkhusus pada materi yang sangat membutuhkan kemampuan siswa dalam penalaran, komunikasi dan koneksi matematis, serta pemecahan masalah.

Berdasarkan uraian di atas, maka penulis terdorong melakukan penelitian yang berjudul: Pengembangan Bahan Ajar Matematika Berbasis Masalah Untuk Memfasilitasi Penalaran Siswa Pada Pokok Bahasan Perbandingan Kelas VII MTsN Model Makassar.

\section{PENGEMBANGAN}

Pengembangan merupakan penelitian yang digunakan untuk menghasilkan produk tertentu, dan menguji keefektitan produk tersebut.

Tujuan dan manfaat pengembangan bahan ajar adalah menyediakan bahan ajar yang sesuai dengan tuntutan kurikulum dengan mempertimbangkan kebutuhan peserta didik, yakni bahan ajar yang sesuai dengan karakteristik dan setting lingkungan sosial peserta didik, membantu peserta didik dalam memperoleh alternatif bahan ajar disamping buku-buku teks yang terkadang sulit diperoleh, memudahkan guru dalam melaksanakan pembelajaran. Menurut Trianto, 2011), manfaat lain yang didapatkan guru dalam pengembagana bahan ajar adalah: (1) diperoleh bahan ajar yang sesuai dengan tuntutan kurikulum dan kebutuhan belajar peserta didik, (2) tidak tergantung lagi kepada buku teks 
yang terkadang sulit untuk diperoleh, (3) memperkaya materi karena dikembangkan dengan menggunakan berbagai referensi, (4) menambah khasanah pengetahuan dan pengalaman guru dalam menulis bahan ajar, (5) membangun komunikasi pembelajaran yang efektif antara guru dan peserta didik, (6) menambah angka kredit jika dikumpulkan menjadi buku dan diterbitkan. Sedangkan manfaat bagi peserta didik antara lain sebagai berikut: (1) kegiatan pembelajaran menjadi lebih menarik, (2) kesempatan untuk belajar secara mandiri dan mengurangi ketergantungan terhadap kehadiran guru, (3) mendapatkan kemudahan dalam mempelajari setiap kompetensi yang harus dikuasainya.

Bahan ajar yang dikembangkan berdasarkan model pembelajaran berbasis masalah, didalamnya mengaplikasikan sintaks berbasis masalah yang dimuat dalam kegiatan-kegiatan siswa dalam proses pembelajaran. Selain itu, setiap sub pokok bahasan dalam bahan ajar di kaitkan dengan masalah-masalah nyata yang diharapkan dapat memacu daya analogis siswa dalam membaca permasalahan sehingga siswa dapat menyelesaikannya secara sistematis dengan tujuan dapat meningkatkan daya nalar siswa.

\section{BAHAN AJAR}

Bahan ajar adalah segala bentuk bahan yang digunakan untuk membantu guru/instruktur dalam melaksanakan kegiatan belajar mengajar dikelas. Bahan yang dimaksud bisa berupa bahan tertulis maupun bahan tidak tertulis. Bahan ajar memiliki peran yang amat penting dalam pembelajaran, yakni sebagai representasi (wakil) dari penjelasan guru di depan kelas.

Menurut Direktorat Pembinaan Sekolah Menengah Atas, bahan ajar berfungsi sebagai pedoman bagi guru yang akan mengarahkan semua aktivitasnya dalam proses pembelajaran, sekaligus merupakan substansi kompetensi yang seharusnya diajarkan kepada siswa, pedoman bagi siswa yang akan mengarahkan semua aktivitasnya dalam proses pembelajaran, sekaligus merupakan substansi kompetensi yang seharusnya dipelajari/dikuasainya, alat evaluasi pencapaian/penguasaan hasil pembelajaran.

\section{PEMBELAJARAN BERBASIS MASALAH}

Menurut Arsyad, (2016), pembelajaran berbasis masalah merupakan model pembelajaran yang menggunakan masalah-masalah nyata dalam 
proses pembelajaran, dengan tujuan agar siswa lebih memahami materimateri yang sedang dipelajari. Adapun sintaks model pembelajaran berbasis masalah, sebagai berikut.

Tabel 1. Sintaks Pembelajaran Berdasarkan Masalah

\begin{tabular}{|c|c|c|}
\hline Tahap & Tingkah Laku Guru & $\begin{array}{c}\text { Aplikasi Pembelajaran } \\
\text { Berbasis Masalah dalam } \\
\text { Bahan Ajar }\end{array}$ \\
\hline $\begin{array}{r}\text { Tah } \\
\text { Orienta } \\
\text { pada } \mathrm{n}\end{array}$ & $\begin{array}{l}\text { Guru menjelaskan tujuan } \\
\text { pembelajaran, menjelaskan } \\
\text { logistik yang dibutuhkan, } \\
\text { mengajukan fenomena atau } \\
\text { demonstrasi atau cerita } \\
\text { untuk memunculkan } \\
\text { masalah, memotivasi siswa } \\
\text { untuk terlibat dalam } \\
\text { pemecahan masalah yang } \\
\text { dipilih. }\end{array}$ & $\begin{array}{l}\text { Mengamati masalah, bagian } \\
\text { ini merupakan fase pertama } \\
\text { dalam sintaks pembelajaran } \\
\text { berbasis masalah yaitu } \\
\text { orientasi siswa pada masalah } \\
\text { yang berisi masalah nyata yang } \\
\text { sengaja disajikan. }\end{array}$ \\
\hline $\begin{array}{r}\text { Taha } \\
\text { Mengory } \\
\text { i siswa } \\
\text { bela }\end{array}$ & $\begin{array}{l}\text { Guru membantu siswa } \\
\text { untuk mendefenisikan dan } \\
\text { mengorganisasikan tugas } \\
\text { belajar yang berhubungan } \\
\text { dengan masalah tersebut. }\end{array}$ & $\begin{array}{l}\text { Mari berdiskusi, bagian ini } \\
\text { merupakan fase kedua dalam } \\
\text { sintaks pembelajaran berbasis } \\
\text { masalah yaitu mengorganisasi } \\
\text { siswa untuk belajar yang berisi } \\
\text { tata cara dalam proses } \\
\text { pembelajaran }\end{array}$ \\
\hline $\begin{array}{r}\text { Tah } \\
\text { Memb } \\
\text { penye } \\
\text { indiv } \\
\text { mat } \\
\text { kelo }\end{array}$ & $\begin{array}{l}\text { Guru mendorong siswa } \\
\text { untuk mengumpulkan } \\
\text { informasi yang sesuai, } \\
\text { melaksanakan eksperimen, } \\
\text { untuk mendapatkan } \\
\text { penjelasan dan pemecahan } \\
\text { masalah. }\end{array}$ & $\begin{array}{l}\text { Menggali informasi, bagian } \\
\text { ini merupakan fase ketiga } \\
\text { dalam sintaks pembelajaran } \\
\text { berbasis masalah yaitu } \\
\text { membimbing penyelidikan } \\
\text { individual maupun kelompok } \\
\text { yang berisi cara untuk } \\
\text { menyelesaikan masalah yang } \\
\text { disajikan }\end{array}$ \\
\hline $\begin{array}{c}\text { Tahap-4 } \\
\text { Mengembangk } \\
\text { an dan } \\
\text { menyajikan } \\
\text { hasil karya }\end{array}$ & $\begin{array}{l}\text { Guru membantu siswa } \\
\text { dalam merencanakan dan } \\
\text { menyiapkan karya yang } \\
\text { sesuai seperti laporan, } \\
\text { video, dan model serta } \\
\text { membantu mereka untuk } \\
\text { berbagi tugas dengan } \\
\text { temannya. }\end{array}$ & $\begin{array}{l}\text { Membuat laporan, bagian ini } \\
\text { merupakan fase keempat } \\
\text { dalam sintaks pembelajaran } \\
\text { berbasis masalah yaitu } \\
\text { mengembangkan dan } \\
\text { menyajikan hasil karya yang } \\
\text { berisi instruksi untuk membat }\end{array}$ \\
\hline
\end{tabular}




\begin{tabular}{cll}
\hline & & $\begin{array}{l}\text { laporan dari penyelesaian } \\
\text { masalah untuk diselesaikan }\end{array}$ \\
Tahap-5 & Guru membantu siswa & Mari berbagi, bagian ini \\
Menganalisis & untuk melakukan refleksi & merupakan fase kelima dalam \\
dan & atau evaluasi terhadap & sintaks pembelajaran berbasis \\
mengevaluasi & penyelidikan mereka dan & masalah yaitu menganilisis \\
proses & proses-proses yang mereka & dan mengevaluasi proses \\
pemecahan & gunakan. & $\begin{array}{l}\text { pemecahan masalah yang } \\
\text { berisi kegiatan siswa dalam } \\
\text { masalah }\end{array}$ \\
& & $\begin{array}{l}\text { mempersentasikan hasil kerja } \\
\text { mereka }\end{array}$ \\
\hline
\end{tabular}

\section{PENALARAN}

Menurut Turmudi (2008), penalaran merupakan suatu kegiatan atau proses berpikir untuk menarik kesimpulan atau membuat pernyataan baru yang didasarkan pada pernyataan sebelumnya dan kebenarannya telah dibuktikan. Indikator-indikator yang digunakan untuk mengetahui kemampuan penalaran siswa dalam penelitian ini yaitu memperkirakan proses penyelesaian, menggunakan pola dan hubungan untuk menganalisa situasi matematik, menyusun argumen yang valid dengan menggunakan langkah yang sistematis dan menarik kesimpulan yang logis.

\section{PENGEMBANGAN BAHAN AJAR MATEMATIKA BERBASIS MASALAH UNTUK MEMFASILITASI PENCAPAIAN KEMAMPUAN PENALARAN}

Dalam proses pembelajaran matematika di kelas pada umumnya, tidak jarang siswa hanya diberi tugas terstruktur dan diberitahu secara tepat teknik apa yang digunakan untuk menyelesaikannya. Proses belajar yang demikian bersifat mekanistik dimana siswa belajar dengan mengikuti instruksi yang diberikan oleh guru. Bahkan tugas yang dinyatakan sebagai tugas pemecahan masalah itu sering hanya merupakan latihan matematika yang biasa diulang dengan metode pemecahan yang sudah jelas.

Masalah dan situasi yang timbul dalam kehidupan sehari-hari, yang mengharuskan siswa untuk memperkirakan proses penyelesaian, menggunakan pola-pola yang diketahui kemudian menghubungkannya untuk menganalisa situasi matematik yang terjadi, menyusun argumen yang valid dengan menggunakan langkah yang sistematis serta dapat menarik kesimpulan yang logis dengan memberikan alasan pada langkah penyelsaiannya, jarang digunakan oleh guru sebagai latihan penggunaan 
keterampilan atau konsep tertentu, sehingga tujuan dari diadakannya pelajaran matematika itu sendiri tidak tercapai.

Jika pembelajaran matematika yang diberikan oleh guru di kelas dimaksudkan agar siswa dapat menggunakan keterampilan mereka secara mandiri dalam kehidupan sehari-harinya, maka seharusnya seorang guru menyadari bahwa sebenarnya siswa butuh kesempatan untuk berlatih memecahkan masalah yang kurang atau bahkan tidakt erstruktur di dalam kelas.

Setiap materi dalam bahan ajar berbasis masalah yang dikembangkan dimulai dengan tugas yang kurang terstruktur yang diharapkan dapat mendorong siswa memperkirakan proses penyelesaian, menggunakan pola-pola yang diketahui kemudian menghubungkannya untuk menganalisa situasi matematik yang terjadi, menyusun argumen yang valid dengan menggunakan langkah yang sistematis serta dapat menarik kesimpulan yang logis dengan memberikan alasan pada langkah penyelsaiannya.

Bahan ajar yang dikembangkan memuat masalah yang dijadikan objek dalam proses pembelajaran, kemudian dari hasil pemecahan tersebut siswa diharapkan mampu menarik kesimpulan yang logis dengan memberikan alasan pada langkah-langkah penyelsaiannya, sehingga siswa secara tidak langsung dapat memahami materi yang di ajarkan dalam kelas melalui penalaran tersebut.

\section{METODE PENELITIAN}

Penelitian ini merupakan penelitian pengembangan atau sering disebut dengan penelitian Research $\mathcal{E}$ Development (RED) dengan mengadaptasi model pengembangan 4-D, yaitu Define, Design, Develop, and Dissminate (Sugiyono, 2013). Produk yang akan dikembangkan dalam penelitian ini adalah bahan ajar berupa modul matematika berbasis masalah untuk memfasilitasi kemampuan penalaran siswa kelas VII SMP/MTs pada pokok bahasan perbandingan. Dengan Subjek coba yaitu siswa kelas VII MTsN Model Makassar. Instrumen pengumpulan data yang digunakan dalam penelitian ini sebagai beriut: (1) untuk mengukur kevalidan yaitu dengan menggunakan lembar validasi ahli, (2) untuk mengukur kepraktisan yaitu dengan menggunakan lembar observasi keterlaksanaan modul, dan (3) untuk mengukur keefektifan aitu dengan menggunakan lembar observasi kemampan guru mengelola pembelajaran, 
angket respons siswa, lembar observasi aktivitas siswa dan tes hasil belajar (THB). Data yang telah dikumpulkan dengan menggunakan instrumeninstrumen seperti yang telah di sebutkan, selanjutnya di analisis secara komutatif dan di arahkan untuk menjelaskan kevalidan, keefektifan dan kepraktisan modul berbasis masalah untuk memfasilitasi kemampuan penalaran siswa. Adapun data hasil uji coba di kelas digunakan untuk menjelaskan keefektifan dan kepraktisan modul berbasis masalah untuk memfasilitasi kemampuan penalaran siswa.

\section{HASIL DAN PEMBAHASAN}

Proses Pengembangan Bahan Ajar Matematika Berbasis Masalah Untuk Memfasilitasi Penalaran Siswa Pada Pokok Bahasan Perbandingan Yang Valid, Praktis Dan Efektif

Pengembangan bahan ajar matematika berbasis masalah dilakukan dengan menggunakan model 4-D. Berikut pembahasannya secara singkat. a. Tahap Pendefenisian (Define). Pertama analisis awal-akhir, analisis ini bertujuan untuk mengidentifikasi masalah-masalah yang dihadapi oleh guru MTsN Model Makassar khsusnya guru matematika yang mengajar di kelas VII. Berdasarkan hasil diskusi dengan guru matematika MTsN Model makassar tentang kegiatan pembelajaran matematika disekolah tersebut, diperoleh bahwa proses pembelajaran matematika di kelas VII MTsN Model Makassar masih berpusat pada guru. Kedua analisis siswa, pada analisis ini, peneliti menelaah tentang latar belakang pengetahuan siswa, bahasa yang digunakan dan tingkat perkembangan kognitif siswa. Ketiga Analisis Konsep, Kegiatan yang dilakukan pada tahap ini adalah mengidentifikasi, merinci, dan menyusun secara sistematis materi-materi utama yang dipelajari siswa, selanjutnya materi tersebut disusun secara sistematis. Keempat analisis tugas, pada tahap ini, peneliti merumuskan tugas berdasarkan indikatr yang ada dalam pokok bahsan perbandingan. Kelima spesifikasi tujuan pembelajaran, dilakukan dengan menjabarkan kompetensi dasar ke dalam indikator pencapaian hasil belajar yang lebih spesifik berdasarkan analisis materi dan analisis tugas.

b. Tahap Perancangan (Design), peneliti mulai merancang bahan ajar matematika berbasis masalah untuk memfasilitasi pencapaian kemampuan penalaran. Hasil perancangan tersebut terdiri dari (1) judul, pada tahap merancang judul dilihat berdasarkan kompetensi 
dasar, indikator yang ingin dicapai, materi pokok, dan didasarkan oleh suatu strategi, maka bahan ajar ini diberi judul "Bahan Ajar Matematika Pokok Bahasan Perbandingan Dengan Menggunakan Model Pembelajaran Berbasis Masalah Kelas VII SMP /MTs", (2) kata pengantar, bagian ini berisi ucapan terima kasih atas terselesaikannya bahan ajar, alasan penulisan bahan ajar secara singkat dan manfaat yang bisa diperoleh dengan membaca bahan ajar tersebut, (3) informasi isi bahan ajar, bagian ini akan memberikan informasi penting tentang isi modul, (4) petunjuk penggunaan bahan ajar, bagian ini ditunjukkan apa saja yang mesti dilakukan pembaca (peserta didik) ketika membaca bahan ajar, (5) daftar isi, bagian ini menginformasikan kepada pembaca tentang topik-topik yang ditampilkan dalam bahan ajar sesuai urutan tampilan dan nomor halaman dengan demikian pembaca mudah untuk melacak materi yang dicari, tanpa harus membuka halaman demi halaman satu per satu, (6) kompetensi dasar, perilaku akhir yang diharapkan dapat diperoleh oleh pembaca dari hasil proses belajar yang ditempuhnya, itulah isi bagian ini, (7) indikator keberhasilan, bagian ini akan memberikan informasi penting tentang keberhasilan yang harus dicapai dalam modul, (8) indikator penalaran, bagian ini akan memberikan informasi penting tentang keberhasilan yang harus dicapai dalam modul, (9) peta konsep, bagian ini akan memberikan informasi penting tentang hubungan antar topik, sehingga pembaca (peserta didik) lebih mudah melihat ruang lingkup materi secara komprehensif, (10) materi pokok, bagian ini berisi sejumlah materi pokok yang akan dibahas agar pembaca (peserta didik) menguasai kompetensi dasar yang ditetapkan, (11) uraian materi, jika materi pokok telah ditentukan, maka pada bagian inilah materi pokok itu dijabarkan dan dijelaskan kebagian-bagian yang lebih rinci dan mendetail. Selain itu, pada bagian ini terdapat aktivitas siswa yang di dasarkan pada sintaks pembelajaran berbasis masalah. Dengan demikian pembaca bisa memahaminya dengan mendalam, (12) tes mandiri, tes ini di berikan pada akhir setiap bab atau akhir setiap kegiatan belajar. Hal ini ditujukan untuk mengukur tingakat penguasaan materi yang dicapai oleh pesertadidik (pembaca) pada setiap kegiatan belajarnya, (13) rangkuman, bagian ini memuat rangkuman materi dalam satu bab, sehingga terletak diakhir materi setiap bab, (14) refleksi, bagian tindak lanjut berisi feedback kepada pembaca. Bagi yang telah menguasai materi, disarankan untuk 
mengembangkan pengetahuan yang telah diperolehnya. Sedangkan bagi yang belum mencapai belajar tuntas, disarankan untuk mengulangi bagian yang masih dirasa sulit, (15) uji kompetensi, tes ini diberikan di akhir bahan ajar untuk melihat penguasaan peserta didik (pembaca) terhadap materi yang sudah dipelajari dalam satu bahan ajar. Waktu yang dibutuhkan untuk menyelesaikan tes akhir ini diusahakan tidak melebihi waktu yang digunakan untuk mempelajari bahan ajar, (16) daftar pustaka, sejumlah referensi yang digunakan sebagai bahan rujukan ditulis dalam bagian ini. Sehingga, jika peserta didik ingin mengetahui secara lengkap atau lebih jauh tentang suatu persoalan dari sumber referensi tertentu, maka dapat dilacak keberadaannya.

c. Tahap pengembangan (develop), pada tahap ini peneliti melakukan Pertama melakukan validasi terhadap bahan ajar yang dibuat untuk memenuhi kriteria pertama pada bahan ajar yaitu valid.

Tabel 2. Hasil Uji Validitas Bahan Ajar Modul

\begin{tabular}{cccc}
\hline No. & $\begin{array}{c}\text { Lembar } \\
\text { Validasi }\end{array}$ & $\begin{array}{c}\text { Rata-rata } \\
\text { Penilaian }\end{array}$ & Kategori \\
\hline 1. & Modul & 4,77 & Sangat Valid \\
\hline
\end{tabular}

Tabel 2, menunjukkan bahwa modul, beserta perangkatnya memiliki nilai rata-rata 4,77 pada kategori sangat valid karena setiap pada bahan ajar modul berada pada interval $4 \leq M \leq 5$ selain itu semua validator memberikan kesimpulan bahwa perangkat yang telah dikembangkan adalah baik dan dapat digunakan dengan sedikit revisi.

Kedua kemudian setelah divalidasi, bahan ajar tersebut di uji coba untuk memenuhi kriteria kepraktisan dengan menggunakan lembar observasi keterlaksanaan bahan ajar.

Tabel 3. Hasil Uji Kepraktisan Bahan Ajar

\begin{tabular}{cccc}
\hline No. & Lembar Penilaian & Rata-rata Penilaian & Kategori \\
\hline 1. & Keterlaksanaan Bahan ajar & 1,95 & $\begin{array}{c}\text { Terlaksana } \\
\text { Seluruhnya }\end{array}$ \\
\hline
\end{tabular}

Tabel 3, menunjukkan rata-rata hasil penilaian keterlaksanaan bahan ajar matematika berbasis masalah untuk memfasilitasi pencapaian kemampuan penalaran adalah 1,95 berada pada kategori terlaksana seluruhnya (praktis) atau berada pada interval 1,5 $\leq \bar{X} \leq 2$. 
Tabel 4. Hasil Uji Keefektifan Perangkat Bahan Ajar

\begin{tabular}{|c|c|c|c|}
\hline No. & Lembar Penilaian & Penilaian & Kategori \\
\hline 1. & THB & Hasil belajar siswa tercapai & Efektif \\
\hline & & $\begin{array}{lcl}\text { karena } & 85 \% & \text { siswa } \\
\text { mencapai skor } 75 & \end{array}$ & \\
\hline 2. & Aktivitas Siswa & $\begin{array}{l}\text { Telah memenuhi kriteria } \\
\text { batas toleransi pencapaian }\end{array}$ & Efektif \\
\hline & & $\begin{array}{l}\text { waktu ideal yang } \\
\text { digunakan }\end{array}$ & \\
\hline 3. & $\begin{array}{l}\text { Kemampuan Guru } \\
\text { Mengelola Pembelajaran }\end{array}$ & $\begin{array}{l}\text { Hasil rata-rata yang } \\
\text { diperoleh yaitu } 3,826389 \\
\text { dan berada pada kriteria } \\
\text { tinggi dalam interval } 3,5 \leq \\
K G<4,5 \text {. }\end{array}$ & Efektif \\
\hline 4. & Angket Respon Siswa & $\begin{array}{l}\text { Hasil respon positif } \\
\text { terhadap bahan ajar modul } \\
\text { yang dikembangkan lebih } \\
\text { dari } 50 \% \text { yaitu } 89,25 \% \text {. }\end{array}$ & Efektif \\
\hline
\end{tabular}

Dari keempat kriteria keefektifan yaitu, kemampuan guru mengelola pembelajaran, aktivitas siswa, respon siswa dan hasil belajar, dapat disimpulkan bahwa pada tahap uji coba terbatas telah dilaksanakan dan perangkat pembelajaran yang berupa bahan ajar matematika berbasis masalah tersebut yang bertujuan untuk memfasilitasi pencapaian kemampuan penalaran siswa telah memenuhi kriteria kevalidan, kepraktisan, dan keefektifan

d. Tahap penyebaran (disseminate) tidak dilakukan karena keterbatasan waktu dan biaya, dengan harapan akan dilanjutkan oleh peneliti selanjutnya.

\section{Kualitas Bahan Ajar Matematika Berbasis Masalah yang Dikembangkan}

Pada bagian ini akan di kemukakan mengenai ketercapaian tujuan penelitian (kualitas pengembangan). Ketercapaian tujuan penelitian yang dimaksud yaitu ketercapaian yang dikaitkan dengan kevalidan, kepraktisan, dan keefektifan bahan ajar matematika berbasis masalah yang dikembangkan.

a. Kevalidan, berdasarkan hasil uji kevalidan yang telah dibahas sebelumnya dapat disimpulkan bahwa prototype awal bahan ajar matematika berbasis masalah untuk memfasilitasi pencapaian 
kemampuan penalaran siswa beserta perangkat pendukungnya yang telah dikembangkan telah memenuhi kriteria kevalidan. Meskipun sebelumnya telah dilakukan beberapa revisi kecil sesuai saran yang diberikan oleh dua validator.

b. Kepraktisan, secara teoritis, hasil penelaian ahli dan praktisi dalam bidang pendidikan matematika terhadap bahan ajar matematika berbasis masalah untuk memfasilitasi pencapaian kemampuan penalaran siswa menyatakan bahwa bahan ajar layak digunakan dalam pembelajaran, sedangkan secara empirik berdasarkan hasil pengamatan terhadap perangkat bahan ajar oleh dua observer menyatakan bahwa perangkat modul terlaksana dengan baik pada saat uji coba. Berdasarkan hasil penilaian pengamat, maka perangkat bahan ajar telah memenuhi kriteria kepraktisan.

c. Keefektifan, kriteria keefektifan bahan ajar, dapat dinilai melalui: (1) hasil belajar siswa atau ketuntasan klasikal, (2) respon siswa, (3) aktivitas siswa, (4) kemampuan guru dalam mengelola pembelajaran. Kriteria yang harus dipenuhi sehingga suatu perangkat bahan ajar dikatakan efektif adalah memenuhi 3 kriteria tetapi idikator ketuntasan hasil belajar harus dipenuhi. Dari hasil uji coba yang dilakukan pada siswa kelas VII MTsN Model Makassar, keempat kriteria yang menuju keefektifan terpenuhi mulai dari 1) Hasil belajar siswa atau ketuntasan klasikal, (2) respon siswa, (3) aktivitas siswa, (4) kemampuan guru dalam mengelola pembelajaran.

\section{SIMPULAN}

Berdasarkan hasil penelitian dan pembahasan, maka dapat ditarik kesimpulan bahwa:

a. Proses pengembangan bahan ajar dengan menggunakan model 4-D yang terdiri dari 4 tahap yaitu pendefenisian (define), perancangan (design), dan pengembangan (develop), dan tahap penyebaran (desseminate).

b. Berdasarkan hasil pengembangan bahan ajar diperoleh bahan ajar yang valid, praktis, dan efektif, yaitu: (a) lembar validasi bahan ajar (modul), validasi bahan ajar modul adalah 4,7 pada kategori sangat valid karena setiap aspek untuk setiap jenis lembar validasi berada pada interval $4 \leq$ $M \leq 5$, sehingga bahan ajar tersebut dikatakan valid, (b) praktis karena berdasarkan hasil pengamatan keterlaksanaan bahan ajar matematika 
berbasis masalah untuk memfasilitasi pencapaian kemampuan penalaran menunjukkan bahwa rata-rata semua komponen pengamatan keterlaksanaan adalah 1,97 dan berada pada kategori terlaksana seluruhnya (praktis) atau berada pada interval 1,5 $\leq \bar{X} \leq 2$, dan (c) efektif karena telah memenuhi empat kriteria yang menjadi acuan yaitu hasil belajar siswa tercapai karena 85\% siswa mencapai skor 75, aktivitas siswa dikatakan ideal, karena telah memenuhi kriteria batas toleransi pencapaian waktu ideal yang digunakan, hasil rata-rata kemampuan guru mengelola pembelajaran yang diperoleh yaitu 3,83 dan berada pada kriteria tinggi dalam interval 3,5 $\leq K G<4,5$, dan diperoleh hasil respon positif terhadap bahan ajar yang dikembangkan lebih dari 50\% yaitu $89,25 \%$.

\section{DAFTAR PUSTAKA}

Arsyad. N. (2016). Model pembelajanran menumbuhkembangkan kemampuan metakognitif. Makassar: Pustaka Refleksi.

Buhaerah, (2011). “Pembelajaran berbasis masalah untuk meningkatkan kemampuan penalaran matematis Siswa SMP". Jurnal Gamatika, 2(1).

Depdiknas. (2008). Panduan pengembangan bahan ajar. Jakarta: Direktorat Pembinaan SMA Dirjen Mandikdasmen Depdiknas. Tersedia di http://www.google.co.id.

Rosnawati, R. (2013). Kemampuan penalaran matematika siswa SMP Indonesia pada TIMSS 2011. Prosiding Seminar Nasional Penelitian, Pendidikan dan Penerapan MIPA ISBN. Tersedia di https://scholar.google.co.id/cit.

Sugiyono. (2013). Metode penelitian kualitatif kuantitatif dan RED. Bandung: Alfabeta.

Sumartini, T. S. (2015). "Peningkatan kemampuan penalaran matematis siswa melalui pembelajaran berbasis masalah". Jurnal Pendidikan Matematika, 5(1), 1-2.

Susiana, N. (2013). Kemampuan penalaran siswa kelas VIII dalam menyelesaikan soal kesebangunan. MATHEdunesa, 2(1).

Turmudi. (2008). Landasan filsafat dan teori pembelajaran matematika siswa dalam pelajaran matematika. Disertasi pada PPS IKIP Bandung. 
Siti Nurhidayati ${ }^{1)}$, Thamrin Tayeb $^{2)}$, Baharuddin ${ }^{3)}$

Trianto. (2011). Mendesain model pembelajaran inovatif-progresif. Jakarta: Kencana Prenada Media Group. 